\title{
MIR125B1 Gene
}

National Cancer Institute

\section{Source}

National Cancer Institute. MIR125B1 Gene. NCI Thesaurus. Code C80751.

This gene is involved in the regulation of gene expression and plays a role in the development of hepatocellular carcinoma. 